\title{
Farklı Deprem Bölgesinde Yaşayan Ortaokul Öğrencilerinin Deprem Konusundaki Bilgi Düzeyleri
}

\author{
The Knowledge Levels of Secondary School Students in Different Earthquake Regions \\ about Earthquake
}

\section{Semra Benzer iD 1 \& Ayşe Arpalık iD 2}

\begin{tabular}{|l|l|}
\hline Geliş/Received: 30.01 .2021 & Kabul/Accepted: 21.06 .2021 \\
\hline
\end{tabular}

\section{$\ddot{O} \mathbf{z}$}

Bu çalışmanın amacı, farklı iki deprem bölgesinde yaşamakta olan ortaokul öğrencilerin deprem konusunda bilgi düzeylerinin çeşitli değişkenler açısından incelenmesidir. Toplumun içinde tüm bireylerinin, özellikle de depremden en fazla etkilenecek grup olan çocuklardan başlayarak ortak bir deprem bilinci oluşturulmaya çalışılmalıdır. Öğrencilerin yaşama uyum sağlamaları, bulundukları çevreyi iyi gözlemlemelerine ve durumlar arasında neden-sonuç iliş̧kisini kurmalarına ve buradan bazı çıkarımlar yapmalarına bağlldır. En iyi öğrenme yöntemlerinden biri de yaparak ve yaşayarak öğrenme yöntemidir. Araştırma türü olarak nicel araştırma yöntemi, araştırma deseni olarak ise tarama (survey) kullanılmıştır. Bu araştırma, Batman ve Çorum illerinde ortaokul da okumakta olan 140 ögrenci ile gerçekleştirilmiş̧tir. Araştırmaya katılan öğrenciler deprem konusundaki bilgilerini kitap $(\% 55,7)$, internet $(\% 61,4)$, ögretmen $(\% 76,4)$, aile ve akraba $(\% 55,7)$, arkadaş ve tanıdık (\%35) ve ulusal ya da yerel dergi gazete, radyo ve televizyon kanallarından $(\% 38,6)$ edindiklerini belirtmektedirler. Araştirma sonucunda ise ortaokul ögrencilerinin deprem bilgi puanlarinda illere ve cinsiyetlere göre istatistiki olarak anlaml bir farklllık tespit edilemezken, 5. sinıf ve 8. sinıf düzeyleri arasinda istatistiki olarak anlaml farklllık gözlenmistir. Test sonuçlarına göre, 8. sinıfta okumakta olan ögrencilerin deprem hakkinda bilgi düzeylerinin 5. sinufta okumakta olan ögrencilere daha yüksek olarak bulunmuştur.

Anahtar Sözcükler: Deprem, Farkındalık, Bilgi düzeyi, Batman, Çorum

\begin{abstract}
This aim is to examine different variables in the secondary school earthquake area living in two different earthquake zones. A common earthquake awareness should be tried to be created in the society, especially starting with the children who will be affected most by the earthquake. Students' adaptation to life depends on their observation of their environment well, establishing a cause-effect relationship between situations and making some inferences from this. One of the best learning methods is learning by doing and experiencing. Quantitative research method was used as research type and survey was used as research design. This research was carried out with 140 students studying at secondary school in Batman and Çorum provinces. The students participating

\footnotetext{
${ }^{1}$ Prof. Dr., Gazi Üniversitesi Gazi Eğitim Fakültesi, Fen Bilgisi Eğitimi Anabilim Dalı, Ankara, Türkiye. E-posta:sbenzer@gazi.edu.tr, https://orcid.org/0000-0002-8548-8994

2 Yüksek Lisans Öğrencisi, Gazi Üniversitesi Eğitim Bilimleri Enstitüsü, Ankara, Türkiye.

E-posta:arpalikayse@gmail.com, https://orcid.org/0000-0003-0872-8453
}

\section{Önerilen Atıf / Suggested Citation:}


in the research learned their knowledge about earthquakes from books (55.7\%), internet (61.4\%), teachers (76.4\%), family and relatives (55.7\%), friends and acquaintances (35\%), and national or local magazines, newspapers, radio and television channels (38.6\%). As a result of the research, while there was no statistically significant difference in earthquake knowledge scores of secondary school students by provinces and gender, a significant difference was observed between grade levels. According to the data obtained, the level of knowledge of the students about the earthquake from studying in the $8^{\text {th }}$ grade was found to be higher than the students who were in the $5^{\text {th }}$ grade.

Key Words: Earthquake, awareness, knowledge level, Batman, Çorum

\section{GíRIŞ}

Doğal afet; deprem, sel, yağış gibi doğal yolla gelen ve önlenmesi insanın elinde olmayan yıkımlardır. Doğal afetlerin çeşitleri ve önem sıraları ülkeden ülkeye de değişmektedir. Ülkemizde ise en sık görülen doğal afetler; yıldırım, dolu, sel, şiddetli yağış, taşkın, orman yangınları, don, kuraklık, şiddetli rüzgâr, çı̆̆, kar, firtına ve depremdir (Sözen, 2019). 20. yüzyılda dünyada gerçekleşen 16 tane büyük deprem gerçekleşmiştir. Ülkemizde gerçekleşen depremlerden iki tanesi “Gölcük ve Erzincan” depremleridir. Sadece 20. Yüzyılda gerçekleşen depremlerde dünyada 1 milyon 548 bin 450 kişi hayatını kaybettiği bilinmektedir. Her yıl binlerce hatta milyonlarca insanın hayatını kaybetmesine sebep olan deprem de günlük yaşam düzenini bozan ve toplumu etkileyen bir doğal afettir (Erol \& Öner, 1999). Deprem ortadan kaldırılabilecek ya da önlenebilecek olay olmadığından, depremden korunmak için neler yapılabileceğini öğrenmeye yönelik eğitim verilerek zararı en aza indirilmeye çalışılmalıdır. Bunun için deprem öncesinde, sırasında ve sonrasında alınması gereken önlemleri belirleyerek bu bilgiler kişilere aktarılmalıdır. Depremlerin etkisini en aza indirmenin yolunu önlem alarak farkındalığı sağlamak ve deprem konusunda da bilincin artırılmasını sağlanabilmektedir (Öcal, 2003).

Bilgi çağının içinde bulunduğumuz bu dönemde Türkiye'de uygulanan eğitim modelinde temel amaç, öğrenciye doğrudan ham bilgiyi aktarmaktan çok, onlara bilgiye ulaşma yollarını göstermek olmalıdır. Milli Eğitim Bakanlığı 2005 yılından itibaren uygulanan ders öğretim programlarında da bu durum hedeflenmektedir (Çomak \& Güncegörü, 2012; Turoğlu, 2006; Sözen, 2019). Bu becerilerin kazandırıldığı derslerin başında fen bilimleri dersleri yer almaktadır. Fen bilimleri derslerinde öğrencilerin yaşamlarını sürdürdükleri doğal çevreyi ve evreni bilimsel yollar kullanarak inceleyip kavramaları hedeflenmektedir. Öğrencilerin yaşama uyum sağlamaları, bulundukları çevreyi iyi gözlemlemelerine ve durumlar arasında nedensonuç ilişkisini kurmalarına ve buradan bazı çıkarımlar yapmalarına bağlıdır. Fen bilimleri dersinin içeriği bireylerin çevrelerinde karşılaştıkları günlük olaylar olduğu için, konuların direk ezberletilerek değil olaylar arasında ilişki kurarak, analiz yaparak, bilimsel inceleme yaparak sonuçları ortaya konulabilmektedir (Kaptan \& Korkmaz, 1999; Sözen, 2019). Bu kapsamda sınırlı sayıda bulunan literatür incelendiğinde de öğrencilerin deprem konusunda ki bilgilerinin kavratılmasında başta fen bilimleri dersleri olmak üzere coğrafya vb derslerin müfredatlarının önemli olduğu ve görülmektedir. Milli Bakanlığı ortaokul 5.sınıf müfredatında Deprem konusunda 6.ünite içerisinde "Yıkıcı Doğa Olayları" bölümü bulunmaktadır. Deprem ile ilgili bu ünitede kazanım olarak "Doğal süreçlerin neden olduğu yıkıcı doğa olaylarını açıklar" ve "Yıkıcı doğa olaylarından korunma yollarını ifade eder." kazanımları bulunmaktadır. Bu konuların etkin şekilde öğretilmesinin, farkındalık oluşturulmasının geleceğin yetişkinlerine deprem bilinci ve farkındalığı sağlanması bakımından çok önemli olduğu bilinmektedir. Bireylerin deprem hakkındaki bilgilere çeşitli kaynaklardan ulaştığı bilinmektedir. 
Alanyazın incelendiğinde deprem konusunda çeşitli branşlarda öğretmen, farklı seviyelerde öğrencileri temel olan pek çok araştırmaya rastlanmıştır (Koca, 2001; Çoruhlu, 2001; Sert, 2002; Öcal, 2003; Öcal, 2005; Demirkaya, 2007; Altay, 2008; Çakar, 2008; Faiz, 2009; Şenaslan, 2010; Öztürk, 2013; Demirci \& Y1ldırım, 2015; Balcı, 2016; Yiğit vd., 2019; Dikmenli \& Yakar, 2019; Kurt \& Gülbahçe, 2019; Yükseler, 2019; Kıvrak, 2019; Yolcu \& Bekler, 2020; Çavuş \& Balçın, 2020; Ertuğrul \& Ünal, 2020). Karakuş (2007), 8. sınıf ögrencilerinin doğal afet ve afet eğitimi kavramını anlama düzeyleri; Karakuş (2013) depremi yaşamış ve yaşamamış öğrencilerin deprem algılarının, metafor analizi, Aksoy \& Sözen (2014), lise öğrencilerinin farklı varyantlarla coğrafya dersinde verilen deprem eğitimine ilişkin seçeneklerinin değerlendirilmesi ve Aksoy (2013), depremi yaşamış olan 9. sınıf öğrencilerinin "deprem" kavramına yönelik algılarının nitel açıdan incelenmesi başlıklı araştırmaları yürütmüşlerdir.

Çorum ve Batman deprem riski fazla olan 2. grup riskli iller arasında bulunmaktadır (AFAD, 2021). Bu araştırmada farklı deprem bölgelerinde bulunan ortaokul öğrencilerinin deprem konusundaki bilgi düzeyleri belirlenmeye çalışılırken, bu bilgileri hangi kaynaklardan ne derece bildiklerini belirlemek amaçlanmıştır. Bu araştırmanın yeni araştırmalar açısından yol gösterici olacağı, elde edilen sonuçların tüm paydaşlar tarafından verimli şekilde değerlendirilmesi beklenmektedir.

\subsection{Problem Durumu}

Araştırmanın problemi: "Farklı Deprem Bölgesinde Yaşayan Ortaokul Öğrencilerinin Deprem Konusundaki Bilgi Düzeyleri” arasında anlamlı farklılık var mıdır şeklinde ifade edilmiştir.

\subsection{Araştırmanın Amacı}

Araştırmanın amacı, farklı deprem bölgesinde yaşayan ortaokul öğrencilerinin deprem konusundaki bilgi düzeylerinin çeşitli değişkenler açısından belirlenmesidir. Deprem bilgi düzeylerinin illere, sınıf düzeyi ve cinsiyete göre değişimi belirlenmek istenmektedir.

\section{YÖNTEM}

\subsection{Araşturma Modeli}

Araştırmada, farklı deprem bölgesinde yaşayan ortaokul öğrencilerinin deprem konusundaki bilgi düzey durumlarını araştırmak amaçlanmıştır. $\mathrm{Bu}$ doğrultuda nicel araştırma yöntemlerinden tarama araştırması yöntemi kullanılmıştır. Tarama araştırması bir topluluğun belirli özelliklerini ortaya çıkarmak için verilerin toplanmasını amaçlamaktadır. Bu çalışma yönteminin en büyük faydalarından biri çok fazla katılımcı ile oluşturulan örneklemle ulaşılan veriler elde edebilmektir (Büyüköztürk, 2020).

\section{2. Çalışma Grubu}

Çalışma; Batman ve Çorum illerinde bulunan Milli Eğitim Bakanlığı'na bağlı iki ortaokulda $5,6,7$ ve 8 . Sınıflarda öğrenim gören, 9-14 yaş aralığında, 75 kadın ve 65 erkek öğrenci olmak üzere toplam 140 öğrenci ile gerçekleştirilmiştir (Tablo 1). Bu araştırmaya Çorum ilinden 70, Batman ilinden 70 öğrencinin katıldığı belirlenmiştir. Araştırmaya katılan öğrencilerin çoğunluğunun kendi evlerinde ikamet ettiği belirlenmiştir. Ayrıca deprem konusundaki bilgilerini kitap, internet, öğretmen, aile- akraba, tanıdıklar - arkadaşlar aracığıyla, ulusal dergi - yerel dergi -radyo - televizyon ve gazete yoluyla edindiklerini bildirmektedirler.

\subsection{Veri Toplama Araçları}

Araştırmada elde edilen veriler yarı yapılandırılmış görüşme formları ile yüz yüze görüşülerek elde edilmiştir. Veri toplama aracı olarak Kıvrak (2019) "Karabük ilinde deprem farkındalığı mevcut durumunun ve deprem eğitiminin öğrenciler üzerindeki etkisinin araştırılması" isimli 
araştırma için Kıvrak (2019) tarafından hazırlanan Cronbach Alpha güvenirlik katsayısı 0,7 hesaplanan deprem ölçeği kullanılmıştır. Araştırmada kullanılan ölçek beş bölümden oluşmakta olup 4'lü likerttir. Kullanılan ölçeğin güvenirlik katsayısı Cronbach alpha değeri 0,7 olarak hesaplanmıştır. Kullanılan ölçek, I. Bölüm: Demografik bilgileri ile ilgili, II. Bölüm: Öğrencilerin deprem konusundaki yaşamsal bilgileri, III. Bölüm: Deprem hakkında genel bilgiler, IV. Bölüm: Deprem öncesi ile ilgili genel bilgiler, V. Bölüm: Deprem anında ile ilgili genel bilgiler, VI. Bölüm: Deprem sonrasında ile ilgili genel bilgiler, bölümlerinden oluşmaktadır. II. bölümde ise bilgiler "Evet" ve "Hayır" şekilde öğrencilerin cevap verebileceği kısmından oluşmaktadır. III., IV., V. ve VI. bölümlerde 4'lü likert tipi kullanılmıştır. "Bilmiyorum", "Katılmıyorum", "Kararsızım” ve "Katılıyorum” şekilde kullanılmıştır.

\subsection{Verilerin Analizi ve Değerlendirilmesi}

Araştırmada toplanan verilerin analizi “SPSS 16" istatistik paket programı ile gerçekleştirilmiştir. Araştırmada kullanılan veriler üzerinde çalışılarak frekans, yüzde, normallik testi, "Mann Whitney-U Testi”, “Khi-kare testi” ve "Tamhane” testi analizleri gerçekleştirilmiştir.

\section{BULGULAR}

\subsection{Demografik Bilgiler}

Araştırmaya katılan öğrencilerin demografik bilgileri frekans ve yüzde olarak Tablo 1.'deki verilmiştir.

Tablo 1. Demografik Bilgiler

\begin{tabular}{|c|c|c|c|}
\hline Demografik Bilgiler & Grup & Frekans & Yüzde(\%) \\
\hline \multirow{2}{*}{ Öğrencilerin bulundukları iller } & Çorum & 70 & 50 \\
\hline & Batman & 70 & 50 \\
\hline \multirow{2}{*}{ Cinsiyet } & Kadın & 75 & 53,6 \\
\hline & Erkek & 65 & 46,4 \\
\hline \multirow{6}{*}{ Yaş } & 9 & 5 & 3,6 \\
\hline & 10 & 31 & 22,1 \\
\hline & 11 & 23 & 16,4 \\
\hline & 12 & 41 & 29,3 \\
\hline & 13 & 32 & 22,9 \\
\hline & 14 & 8 & 5,7 \\
\hline \multirow{4}{*}{ Sinif } & 5.Sinıf & 40 & 28,6 \\
\hline & 6.Sinif & 31 & 22,1 \\
\hline & 7.Sinif & 30 & 27,9 \\
\hline & 8.Sinif & 39 & 27,9 \\
\hline \multirow{4}{*}{ Gelir durumları } & $0-1000$ & 62 & 44,3 \\
\hline & $1000-2500$ & 50 & 35,7 \\
\hline & $2500-4000$ & 17 & 12,1 \\
\hline & $4000-5000$ & 11 & 7,9 \\
\hline \multirow{2}{*}{ İkamet durumları } & Kendi evi & 94 & 67,1 \\
\hline & Kira & 37 & 26,4 \\
\hline
\end{tabular}




\begin{tabular}{llll}
\hline & Yurt & 3 & 2,1 \\
& Diğer & 4 & 2,9 \\
\hline & Kitap & 78 & 55,7 \\
& İnternet & 86 & 61,4 \\
& Öğretmen & 107 & 76,4 \\
Afetler hakkında hangi kaynaklardan & Aile, Akraba & 78 & 55,7 \\
bilgi edinme yolları & Arkadaşlar ve tanıdıklar & 49 & 35 \\
& Ulusal ya da yerel dergi, gazete, & 54 & 38,6 \\
& radyo ve televizyon & & \\
\hline
\end{tabular}

Araştırmaya Çorum ve Batman illerinden ortaokul 5., 6., 7. ve 8. sınıf seviyesinden 9-14 yaş aralığında, toplam 140 öğrencinin katıldığı, bunların 75'inin kadın 65'inin erkek bireyler olduğu belirlenmiştir (Tablo1). Araştırmaya katılan öğrencilerin, deprem konusundaki yaşamsal bilgileri verdikleri yanıtlar frekans ve yüzde olarak Tablo 2.'de verilmiştir.

Tablo 2. Öğrencilerin Deprem Konusundaki Yaşamsal Bilgileri

Bu araştırmada, öğrencilerin \%25'i herhangi bir afete maruz kaldığı, \%75'i ise herhangi bir

\begin{tabular}{|c|c|c|c|}
\hline Belirtilen Durumlar & Grup & Frekans & $\begin{array}{l}\text { Yüzde } \\
(\%)\end{array}$ \\
\hline \multirow{2}{*}{$\begin{array}{l}\text { Herhangi bir afete maruz kalan kişiler (Örneğin; deprem, sel, heyelan } \\
\text { vb. gibi) }\end{array}$} & Evet & 35 & 25,0 \\
\hline & Hayır & 105 & 75,0 \\
\hline \multirow[b]{2}{*}{ Yakın zamanda deprem konusu herhangi bir derste alan kişiler } & Evet & 96 & 68,6 \\
\hline & Hayır & 44 & 31,4 \\
\hline \multirow[b]{2}{*}{ Evinde afet çantasının olup olmaması durumu } & Evet & 29 & 20,7 \\
\hline & Hayır & 111 & 79,3 \\
\hline \multirow[b]{2}{*}{ Evinde yangın söndürücünün olup olmaması durumu } & Evet & 31 & 22,3 \\
\hline & Hayır & 108 & 77,6 \\
\hline \multirow{2}{*}{$\begin{array}{l}\text { Evinizde afet sırasında sığınabileceğiniz güvenli bir yerin belirlenip } \\
\text { belirlenmesi durumu }\end{array}$} & Evet & 74 & 53,7 \\
\hline & Hayır & 64 & 46,3 \\
\hline \multirow{2}{*}{$\begin{array}{l}\text { Elektrik sigortası, su ve doğal gaz vanasının nasıl kapatıldığını biliyor } \\
\text { olması durumu }\end{array}$} & Evet & 87 & 62,6 \\
\hline & Hayır & 52 & 37,4 \\
\hline \multirow{2}{*}{ Oturdukları evin depreme dayanıklı olup olmaması durumu } & Evet & 95 & 68,9 \\
\hline & Hayır & 43 & 31,1 \\
\hline \multirow[b]{2}{*}{ Olası bir depremde neler yapılacağını biliyor olup olmaması durumu } & Evet & 120 & 87 \\
\hline & Hayır & 18 & 13 \\
\hline \multirow{2}{*}{ Depremden korkup korkma durumu } & Evet & 102 & 74,5 \\
\hline & Hayır & 35 & 25,5 \\
\hline
\end{tabular}

afete maruza kalmadı̆̆ı, \%68,6's1 yakın zamanda deprem konusunda eğitim alırken, \% 31,4'ü ise yakında zamanda deprem konusu hakkında bir eğitim almadığı belirlenmiştir. Araştırmaya katılanlar arasında evinde deprem çantası bulunan 29 öğrenci varken, 111 öğrencinin evinde ise deprem çantası olmadığı belirlenmiştir. Araştırmaya katılan öğrencilerden evinde yangın söndürücü bulunan 31 öğrenci varken, 108 öğrencinin evinde ise yangın söndürücü 
bulunmadığı belirlenmiştir. Çalışmada yer alan 120 öğrencinin bir deprem olması durumunda deprem anında neler yapılması gerektiğini bildiğini, 18 öğrenci ise deprem olduğunda neler yapması gerektiğini bilmediğini ifade ettiği belirlenmiştir (Tablo 2).

$\mathrm{Bu}$ çalışmada elde edilen veriler 1şığında, öğrencilerin deprem konusunda bilgi düzeylerinin cinsiyete bağlı olarak nasıl değiştiğini belirleyebilmek için, il bazında cinsiyetlere göre öğrencilerin bilgi düzeyi puan ortalamaları değerlendirilmiştir. Her iki ilde de kadın öğrencilere ait bilgi düzeyleri puan ortalamaların erkeklerden yüksek olduğu belirlenmiştir (Tablo 3).

Tablo 3. İllere Göre Cinsiyet Deprem Bilgi Düzeyi Puanları

\begin{tabular}{|c|c|c|c|c|}
\hline \multirow{2}{*}{ Yaşadıkları il } & \multirow{2}{*}{ Cinsiyet } & \multicolumn{2}{|c|}{ Deprem Bilgi Düzeyi } & \multirow{2}{*}{ Frekans } \\
\hline & & Ortalama & Standart Sapma & \\
\hline \multirow[t]{3}{*}{ Çorum } & Kadın & 2,88 & 0,44 & 35 \\
\hline & Erkek & 2,77 & 0,55 & 35 \\
\hline & Toplam & 2,82 & 0,49 & 70 \\
\hline \multirow[t]{3}{*}{ Batman } & Kadın & 3,01 & 0,46 & 40 \\
\hline & Erkek & 2,91 & 0,43 & 30 \\
\hline & Toplam & 2,97 & 0,45 & 70 \\
\hline
\end{tabular}

$\mathrm{Bu}$ çalışmada, öğrencilerin deprem konusundaki bilgi düzeylerinin yaşadıkları iller baz alındığında sınıf düzeylerine göre nasıl değiştiğini belirleyebilmek için yapılan incelemelerde Çorum ilinde en yüksek bilgi düzeyi puan ortalamasına 3,09 puan ile 8. Sınıf öğrencilerinin, yine Batman ilinde ise en yüksek bilgi düzeyi puan ortalamasına 3,06 ile 8. Sınıf öğrencilerinin sahip olduğu belirlenmiştir (Tablo 4).

Tablo 4. İllere Göre Sınıf Deprem Bilgi Düzeyi

\begin{tabular}{|c|c|c|c|c|}
\hline \multirow{2}{*}{ Cinsiyet } & \multirow{2}{*}{ Sinıf } & \multicolumn{2}{|c|}{ Deprem Bilgi Düzeyi } & \multirow{2}{*}{ Frekans } \\
\hline & & Ortalama & Standart sapma & \\
\hline \multirow[t]{5}{*}{ Çorum } & 5. sinif & 2,71 & 0,47 & 21 \\
\hline & 6.sinif & 2,61 & 0,56 & 15 \\
\hline & 7.sinif & 2,88 & 0,43 & 16 \\
\hline & $8 . \sin 1 f$ & 3,09 & 0,42 & 18 \\
\hline & Toplam & 2,82 & 0,49 & 70 \\
\hline \multirow[t]{5}{*}{ Batman } & 5. sinif & 2,83 & 0,42 & 19 \\
\hline & 6.sinif & 3,00 & 0,54 & 16 \\
\hline & 7.sinif & 2,97 & 0,34 & 14 \\
\hline & 8.sinif & 3,06 & 0,47 & 21 \\
\hline & Toplam & 2,97 & 0,45 & 70 \\
\hline
\end{tabular}

Araştırmaya katılan farklı sınıf seviyelerindeki kadın ve erkek öğrencilerin deprem bilgi puan düzeyleri incelendiğinde sınıf düzeylerine göre en yüksek deprem bilgi düzeyi puanlarına Batman ilinde 8 . Sınıf kadın $(3,19)$ ve yine Çorum ilinde 8.sınıf erkek $(3,19)$ öğrencilerinin sahip olduğu belirlenmiştir (Tablo 5). 
Tablo 5. Sınıf Seviyesi İle Deprem Bilgi Düzeyi Arasındaki İlişki

\begin{tabular}{|c|c|c|c|c|c|}
\hline \multirow{2}{*}{ Cinsiyet } & \multirow{2}{*}{ Sinıf } & \multirow{2}{*}{ Yaşadıkları il } & \multicolumn{2}{|c|}{ Deprem Bilgi Düzeyi } & \multirow{2}{*}{ Frekans } \\
\hline & & & Ortalama & Standart sapma & \\
\hline \multirow{15}{*}{ Kadın } & \multirow{3}{*}{ 5. sinıf } & Batman & 2,76 & 0,38 & 12 \\
\hline & & Çorum & 2,62 & 0,38 & 8 \\
\hline & & Toplam & 2,70 & 0,38 & 20 \\
\hline & \multirow{3}{*}{ 6.sinıf } & Batman & 3,06 & 0,50 & 9 \\
\hline & & Çorum & 3,14 & 0,26 & 5 \\
\hline & & Toplam & 3,09 & 0,42 & 14 \\
\hline & \multirow{3}{*}{ 7.sınıf } & Batman & 3,07 & 0,37 & 8 \\
\hline & & Çorum & 2,80 & 0,45 & 11 \\
\hline & & Toplam & 2,91 & 0,44 & 19 \\
\hline & \multirow{3}{*}{ 8.sinif } & Batman & 3,19 & 0,51 & 11 \\
\hline & & Çorum & 3,02 & 0,44 & 11 \\
\hline & & Toplam & 3,11 & 0,48 & 22 \\
\hline & \multirow{3}{*}{$\begin{array}{l}\text { Genel } \\
\text { Toplam }\end{array}$} & Batman & 3,01 & 0,46 & 40 \\
\hline & & Çorum & 2,88 & 0,44 & 35 \\
\hline & & Toplam & 2,95 & 0,46 & 75 \\
\hline \multirow{15}{*}{ Erkek } & \multirow{3}{*}{ 5. sinıf } & Batman & 2,95 & 0,48 & 7 \\
\hline & & Çorum & 2,77 & 0,52 & 13 \\
\hline & & Toplam & 2,83 & 0,51 & 20 \\
\hline & \multirow{3}{*}{6. sinıf } & Batman & 2,91 & 0,60 & 7 \\
\hline & & Çorum & 2,35 & 0,49 & 10 \\
\hline & & Toplam & 2,58 & 0,60 & 17 \\
\hline & \multirow{3}{*}{ 7.sinif } & Batman & 2,85 & 0,28 & 6 \\
\hline & & Çorum & 3,05 & 0,35 & 5 \\
\hline & & Toplam & 2,94 & 0,32 & 11 \\
\hline & \multirow{3}{*}{ 8.sinıf } & Batman & 2,92 & 0,40 & 10 \\
\hline & & Çorum & 3,19 & 0,39 & 7 \\
\hline & & Toplam & 3,03 & 0,41 & 17 \\
\hline & \multirow{3}{*}{$\begin{array}{l}\text { Genel } \\
\text { Toplam }\end{array}$} & Batman & 2,91 & 0,43 & 30 \\
\hline & & Çorum & 2,77 & 0,55 & 35 \\
\hline & & Toplam & 2,84 & 0,50 & 65 \\
\hline
\end{tabular}

Araştırmada öğrencilerin deprem bilgi düzeyi ile yaşadıkları iller arasında anlamlı bir fark olup olmadığını belirlemek için öncelikli olarak normal testi yapılmış ve elde edilen verilerin normallik testine göre normal dağılım göstermediği belirlenmiştir. Bu kapsamda, "NonParametrik Mann Whitney-Testi” gerçekleştirilerek anlamlılık düzeyi hesaplanmıştır (Tablo 6).

Tablo 6. İllere Göre Deprem Bilgi Düzeyleri

\begin{tabular}{llllll}
\hline Yaşadıkları il & Frekans & Ortalama & Mann-Whitney-U & Z & p \\
\hline Batman & 70 & 2,96 & 2030,500 & $-1,748$ & 0,080 \\
Çorum & 70 & 2,87 & & &
\end{tabular}

Araştırmada elde edilen veriler incelendiğinde, öğrencilerin deprem konusundaki bilgi düzeyi ile yaşadıkları iller arasında istatistiksel olarak anlamlı bir farklılık olmadığı belirlenmiştir $(\mathrm{p}=0,08, \mathrm{p}<0,05)$ (Tablo 6). 
Araştırmada yer alan öğrencilerin deprem konusunda cinsiyete göre bilgi düzeyleri arasında istatistiksel olarak anlamlı bir fark olup olmadığını belirlemek ve verilerin normal dağılıp dağılmadığını belirlemek amacıyla verilere normallik testi yapılmıştır. Normallik testine göre verilerin normal dağılım göstermediği belirlenmiştir. Bu safhada "Non-Parametrik Mann Whitney-U Testi” gerçekleştirilerek anlamlılık düzeyi hesaplanmıştır (Tablo 7).

Tablo 7. Cinsiye Göre Deprem Bilgi Düzeyi

\begin{tabular}{llllll}
\hline Cinsiyet & Frekans & Ortalama & Mann-Whitney-U & Z & p \\
\hline Kadın & 75 & 2,96 & 2133,000 & $-1,272$ & 0,203 \\
Erkek & 65 & 2,87 & & & \\
\hline
\end{tabular}

Araştırmada elde edilen verilere göre, öğrencilerin deprem konusundaki bilgi düzeyi ile cinsiyet arasında istatistiksel olarak anlamlı bir farklılık olmadığı belirlenmiştir $(p=0,203, p<0,05)$ (Tablo 7).

Araştırmaya katılan öğrencilerin deprem bilgi düzeyi ile sınıf düzeyleri arasında istatistiksel olarak anlamlı bir fark olup olmadığı belirleyebilmek için elde edilen verilerin normallik testine tabi tutulması sonucunda verilerin normal dağılım göstermediği belirlenmiştir. Bu kapsamda, istatistiksel hesaplamalarda Khi-kare testi kullanılmıştır (Tablo 8).

Tablo 8. Sınıf Düzeylerine Göre Deprem Bilgi Düzeyi

\begin{tabular}{lllll}
\hline Sinıf & Frekans & Ortalama & Khi-kare Değeri & p \\
\hline $5 . \sin 1 f$ & 40 & 2,77 & 11,443 & 0,01 \\
$6 . \sin 1 f$ & 31 & 2,81 & & \\
$7 . \sin 1 f$ & 30 & 2,92 & & \\
$8 . \sin 1 f$ & 39 & 3,07 & & \\
\hline
\end{tabular}

Araştırmada elde edilen veriler incelendiğinde öğrencilerin deprem konusundaki bilgi düzeyi ile sınıf düzeyleri arasında istatistiksel olarak anlamlı bir fark bulunduğu gözlenmiştir $(p=0,01$, $\mathrm{p}<0$,05) (Tablo 8). Bu kapsamda yapılan “Tamhane” testi sonucunda 5. sinıfta okumakta olan öğrenciler ve 8.sınıfta okumakta olan öğrencilerin deprem konusundaki bilgi düzeyi aralarında istatistiksel olarak anlamlı bir fark olduğu belirlenmiştir $(p=0,019, p<0,05)$ (Tablo 8).

\section{TARTIŞMA VE SONUÇ}

Farklı iki deprem bölgesinde bulunan ortaokul öğrencilerinin deprem bilgi düzeylerini belirlemek amacıyla yürütülen bu araştırmada, Çorum ve Batman illerinden ortaokul 5., 6., 7. ve 8. sınıf seviyesinden 9-14 yaş aralığında, toplam 140 öğrencinin katıldığı, bunların 75 'inin kadın 65'inin erkek bireyler olduğu belirlenmiştir. Literatür incelendiğinde ortaokul öğrencilerinin deprem konusundaki bilgi düzeylerine ilişkin çok fazla çalışmaya rastlanılmamıştır.

Araştırmaya katılan öğrenciler deprem konusundaki bilgilerini kitap (\%55,7), internet $(\% 61,4)$, öğretmen $(\% 76,4)$, aile ve akraba $(\% 55,7)$, arkadaş ve tanıdık $(\% 35)$ ve ulusal ya da yerel dergi gazete, radyo ve televizyon kanallarından $(\% 38,6)$ edindiklerini belirtmektedirler.

Kıvrak (2019) araştırmasının sonucunda ise öğrencilerin afetler hakkında bilgilerini sırasıyla; $\% 27,7$ arkadaş ve tanıdıklardan, \%39,8 ulusal ya da yerel dergi, gazete, radyo ile televizyondan, $\% 50,1$ aile ile akrabalardan, \%50,9 kitaplardan, \%63,2 internetten ve \%67,7 öğretmenler aracılığ 1 ile edindiklerini belirttiklerini bildirmektedir. 
Araştırmaya katılan öğrencilerden yalnızca 35'inin depreme şahit olduğu, sadece 29'unun evinde deprem çantası 31'inin evinde yangın söndürücü bulunduğu belirlenmiştir. $\mathrm{Bu}$ araştırmada elde edilen veriler incelendiğinde, öğrencilerin \%25’i herhangi bir afete maruz kaldığ $1, \% 75$ 'i ise herhangi bir afete maruza kalmadığ1, \%68,6's1 yakın zamanda deprem konusunda eğitim alırken, \%31,4'ü ise yakında zamanda deprem konusu hakkında bir eğitim almadığı belirlenmiştir. Araştırmaya katılanlar arasında evinde deprem çantası bulunan 29 öğrenci varken, 111 öğrencinin evinde ise deprem çantası olmadığı belirlenmiştir. Araştırmaya katılan öğrencilerden evinde yangın söndürücü bulunan 31 öğrenci varken, 108 öğrencinin evinde ise yangın söndürücü bulunmadığı belirlenmiştir. Çalışmada yer alan 120 öğrencinin bir deprem olması durumunda deprem anında neler yapılması gerektiğini bildiğini, 18 öğrenci ise deprem olduğunda neler yapması gerektiğini bilmediğini ifade ettiği belirlenmiştir.

Farklı araştırmacılar tarafından elde edilen sonuçlar, ortaöğretim öğrencilerinin depremle ilgili davranışlarının uygun bir deprem bilincine sahip olma açısından bilgi ve tutumlarına göre daha yeterli olduğunu göstermektedir. Öğrencilerin sadece \%14 ünün olası bir deprem anında ailece evde yapılması gerekenler konusunda bir deprem planı yaptıklarını belirlenmiştir (Demirci \& Yıldırım, 2015). Öğrencilerde deprem bilinci oluşmasında ilk ve ortaöğretim eğitiminin, öğrencilerin kişisel çaba ve deneyimlerinin ve aile ve toplumunda önemli katkıları olduğu iddia edilmektedir (Shaw vd., 2004). Sınıf öğretmeni adaylarının orta düzeyde deprem bilgisi, deprem öncesi bilgi, deprem anı bilgi ve genel deprem bilgi düzeyine, düşük düzeyde deprem sonrası bilgi düzeyine sahip olduklarını belirtmektedirler (Tekin \& Dikmenli, 2021). Öcal (2007) öğretmen adaylarının deprem hakkında yeterli bilgiye sahip olmadığını belirtilmiştir. Kıvrak (2019), deprem eğitimi sonrasında deprem bilgilerinde anlamlı bir farklılık bulunduğunu alınan eğitimin önemli olduğunu belirtmektedir.

Altay (2008) deprem konusunda ders kitaplarını da yeterince bilgiye yer verilmediğini bildirmektedir. Şenaslan (2010), araştırmada yer alan öğrencilerin sayısal ya da sözel alanında okuyor olmalarının deprem konusunda bilgilerinde anlamlı bir fark gözlenmesine neden olduğunu bildirmektedir. Çakar (2008) sosyal bilgiler öğretmenlerinin, sınıf içinde bulunan öğrencilerin tahliyesini nasıl yapılması gerektiği bildiklerini belirtmektedirler. Benzer şekilde yapılan araştırmalar her eğitim düzeyinde, deprem konusunda bilgi verilmesi ve bilinçlendirmenin önemli olduğunu göstermektedir.

Farklı sınıf seviyelerindeki kadın ve erkek öğrencilerin deprem bilgi puan düzeyleri incelendiğinde sınıf düzeylerine göre en yüksek deprem bilgi düzeyi puanlarına Batman ilinde 8. Sınıf kadın, Çorum ilinde 8.sınıf erkek öğrencilerinin sahip olduğu belirlenmiştir. Çorum ilinde en yüksek bilgi düzeyi puan ortalamasına 3,09 puan ile 8. sınıf öğrencilerinin, yine Batman ilinde ise en yüksek bilgi düzeyi puan ortalamasına 3,06 ile 8. sınıf öğrencilerinin sahip olduğu belirlenmiştir. Elde edilen verilere göre, 8. sınıfta okumakta olan öğrencilerin deprem hakkında bilgi düzeyleri 5.sınıfta okumakta olan öğrencilere göre daha yüksek olarak bulunmuştur. Araştırmaya katılan 8.sınıf öğrencilerin deprem bilgi düzeyleri ile 5. sınıf öğrencilerinin bilgi düzeylerinde anlamlı farklılık bulunduğu tespit edilmiştir. Araştırmada elde edilen bulgular literatürdeki bazı çalışmalardan farklılık göstermektedir. Faiz (2009), deprem bilgisinin müfredatta 5 .sınıfta bulunması ve öğretilmesi 5.sınıfta okumakta olan öğrencilerin deprem bilgilerinin yüksek olmasına neden olduğunu ve deprem anında yapılması gereken davranışların eğitim alan öğrenciler tarafından bilindiğini belirtmektedir

Araştırmada elde edilen veriler incelendiğinde, öğrencilerin deprem konusundaki bilgi düzeyi ile yaşadıkları iller arasında istatistiksel olarak anlamlı bir farklılık olmadığı belirlenmiştir.

Araştırmada elde edilen verilere göre, öğrencilerin deprem konusundaki bilgi düzeyi ile cinsiyet arasında istatistiksel olarak anlamlı bir farklılık olmadığı belirlenmiştir. Araştırmada elde edilen 
veriler incelendiğinde öğrencilerin deprem konusundaki bilgi düzeyi ile sınıf düzeyleri arasında istatistiksel olarak anlamlı bir fark bulunduğu gözlenmiştir

Balcı (2016), deprem travmasının ortaokul öğrencileri üzerinde korku, şaşkınlık, üzüntü, panik, çaresizlik ve pişmanlık/suçluluk, ölüm/can kaybı, sarsıntı/sallantı gibi duygusal ve fiziksel etkiler oluşturduğunu belirtmektedir. İlköğretim öğrencilerinin deprem gerçekleştikten sonra okula gitme isteklerinde, ders başarılarında ve öğrencilerin motivasyonların da anlamlı fark tespit edildiği bildirilmektedir (Sert, 2002). Bu kapsamda her düzeyde bilgi ve farkındalık oluşturmanın olumsuz durumların ortadan kaldırılmasında önemli olduğu düşünülmektedir.

\section{1. Öneriler}

Araştırma sonucunda elde edilen veriler değerlendirildiğinde, ortaokul öğrencilerin bilgi ve farkındalıklarını artırmak için öğrenciler ile "Deprem simülasyon merkezlerine" okul dışı öğrenme etkinlikleri düzenlenebilir. Ayrıca "Gezici simülasyon tırı" okulla davet edilerek öğrencilere deprem eğitiminin verilmesinin bilgi ve farkındalığı artırmasının uygun olabileceği düşünülmektedir. Eğitim-Öğretim yılı içinde okul içinde düzenli ve programlı bir şekilde deprem anında neler yapılabileceğini öğrencilerin deneyerek öğrenmesini sağlamak için tekrarlı tatbikat programlarının düzenlenmesinin uygun olacağı değerlendirilmektedir. Okullarda deprem konusu işlenirken, daha önce yaşanmış ve deprem izleri taşıyan görsel kullanılarak öğrencilerin dikkatlerinin çekilmesi hedeflenmelidir. Deprem konusunda müfredatta konu ağırlığının ve ders saati süresinin yeniden düzenlenmesinin bir çözüm olabileceği düşünülmektedir.

Etik Beyan: $\mathrm{Bu}$ araştırmanın kavramsal çerçevesinin hazırlanmasında, verilerin toplanması, analizi ve yorumlanması aşamalarının tamamında etik kurallara uygun hareket edilmiştir. Yazarların makaleye katkı oranları eşittir. Karşılaşılacak tüm etik ihlallerde ANKAD Dergisi Yayın Kurulunun hiçbir sorumluluğu bulunmamaktadır. Tüm sorumluluk yazarlara aittir. Bu çalışmanın ANKAD Dergisi dışında herhangi bir akademik yayın ortamına değerlendirme için gönderilmemiş olduğunu taahhüt ederiz.

\section{KAYNAKÇA}

AFAD (2021). Türkiye deprem tehlike haritaları. https://www.turkiye.gov.tr/afad-turkiyedeprem-tehlike-haritalari.

Aksoy, B. (2013). Depremi yaşamış olan 9. sınıf öğrencilerinin" deprem" kavramına yönelik algılarının nitel açıdan incelenmesi. Zeitschrift für die Welt der Türken/Journal of World of Turks, 5(1), 247-265.

Aksoy, B., \& Sözen, E. (2014). Lise öğrencilerinin coğrafya dersindeki deprem eğitimine ilişkin görüşlerinin çeşitli değişkenler açısından incelenmesi (Düzce ili örneği). Uşak Üniversitesi Sosyal Bilimler Dergisi, 7(1), 279-297.

Altay, S. (2008). İlköğretimde sosyal bilgiler dersinde depremle ilgili konuların irdelenmesi. Yüksek Lisansı Tezi, Abant İzzet Baysal Üniversitesi, Sosyal Bilimler Enstitüsü, Bolu. 
Balcı, L. (2016). Deprem travmasının kuşaklar arası aktarımının ortaokul öğrencileri üzerinden incelenmesi. Yüksek Lisansı Tezi, Marmara Üniversitesi, Eğitim Bilimleri Enstitüsü, İstanbul.

Büyüköztürk, Ş. (2020). Sosyal bilimler için veri analizi el kitabı (28. Baskı). Ankara: Pegem Akademi Yayınları.

Çakar, Ö. (2008). İlköğretim 5. sınıf sosyal bilgiler dersinin deprem bilinci geliştirmedeki rolüne dair ögrretmen görüşleri. Yüksek Lisansı Tezi, Fırat Üniversitesi, Sosyal Bilimler Enstitüsü, Elazı̆g.

Çavuş, R., \& Balçın, M.D. (2020). Deprem eğitim merkezi gezisinin ortaokul öğrencilerinin depreme yönelik tutumlarına etkisinin incelenmesi. Gaziantep Üniversitesi Ĕ̈itim Bilimleri Dergisi, 4(2), 55-72.

Çomak, N. \& Güncegörü, B. (2012). Coğrafya dersi öğretim programının kazanım saatlerine göre değerlendirilmesi. Marmara Coğrafya Dergisi, 287-301.

Çoruhlu, E. (2001). Deprem bölgesinde yaşayan ilköğretim birinci kademe öğretmenlerinin stres ile başa çıkma yolları (Sakarya ili örneği). Yüksek Lisansı Tezi, Marmara Üniversitesi, Eğitim Bilimleri Enstitüsü, İstanbul.

Demirci, A. \& Yıldırım, S. (2015). İstanbul'da ortaöğretim öğrencilerinin deprem bilincinin değerlendirilmesi. Milli Ĕ̆itim Dergisi, 45(207), 89-118.

Demirkaya, H. (2007). İlköğretim 5. 6. ve 7. Sınıf öğrencilerinin depreme yönelik tutumlarının çeşitli değişkenlere göre incelenmesi, Türkiye Sosyal Araştırmalar Dergisi, 11(3), 37-49.

Dikmenli, Y. \& Yakar, H. (2019). Öğretmen adaylarının afet bilinci alg1 düzeylerinin incelenmesi. Yüzüncü Yıl Üniversitesi Eğitim Fakültesi Dergisi, 16(1), 386-416.

Erol, N. \& Öner, Ö. (1999). Travmaya psikolojik tepkiler ve bunlara yaklaşım. Türk Psikoloji Bülteni, 5(4), 40-49.

Ertuğrul, B. \& Ünal, S.D. (2020). Bir vakıf üniversitesi sağlık hizmetleri meslek yüksekokulunda öğrenim gören öğrencilerin genel afete hazırlıklı olma inanç durumlarının belirlenmesi. Afet ve Risk Dergisi, 3(1), 31-45.

Faiz, M. (2009). 17 Ăgustos ve 12 Kasım 1999 depremlerinin Gölyaka (Düzce) ilçesine bağlı ilköğretim okulları öğrencileri tarafından algılanışı. Yüksek Lisansı Tezi, Abant İzzet Baysal Üniversitesi Sosyal Bilimler Enstitüsü, Bolu.

Kaptan, F. \& Korkmaz H. (1999). Fen öğretimi, MEB-Unicef projesi, etkin öğrenme öğretme ögretmen el kitabl, Ankara.

Karakuş, U. (2013). Depremi yaşamış ve yaşamamış öğrencilerin deprem algılarının metafor analizi ile incelenmesi. Doğu Coğrafya Dergisi, 18(29), 97-116.

Karakuş, U. \& Önger, S. (2017). The Understanding Levels on Natural Disasters and Disasters Education Concepts for $8^{\text {th }}$ Grade Students Students. Journal of History Culture and Art Research, 6(6), 482-491. 
Kıvrak. Ö. (2019). Karabük ilinde deprem farkındalı̆̆ mevcut durumunun ve deprem ĕgitiminin öğrenciler üzerindeki etkisinin araştırılması. Yüksek Lisansı Tezi, Karabük Üniversitesi, Fen Bilimleri Enstitüsü, Karabük.

Koca, M. (2001). Illköğretimde deprem ve depremin zararlarından korunma yollarının ögretimi. Yüksek Lisansı Tezi, Atatürk Üniversitesi, Sosyal Bilimler Enstitüsü, Erzurum.

Kurt, E. \& Gülbahçe, A. (2019). Van depremini yaşayan öğrencilerin travma sonrası stres bozukluğu düzeylerinin incelenmesi. Atatürk Üniversitesi Sosyal Bilimler Enstitüsü Dergisi, 23(3), 957-972.

Öcal, A. (2003). İlköğretim sosyal bilgiler dersinde deprem eğitiminin değerlendirilmesi. Yüksek Lisansı Tezi, Gazi Üniversitesi, Eğitim Bilimleri Enstitüsü, Ankara.

Öcal, A. (2005). İlköğretim sosyal bilgiler dersinde deprem eğitiminin değerlendirilmesi. Gazi Üniversitesi Gazi Ĕ̈itim Fakültesi Dergisi, 25(1), 169-184.

Öcal, A. (2007). İlköğretim aday öğretmenlerinin deprem bilgi düzeyleri üzerine bir araştırma. Mehmet Akif Ersoy Üniversitesi Eğitim Fakültesi Dergisi, 8(1), 104-110.

Öztürk, M.K. (2013). Sınıf öğretmeni adaylarının deprem deneyimleri üzerine bir araştırma. Hacettepe Üniversitesi Eğitim Fakültesi Dergisi, 28(28-1), 308-319.

Sert, E. (2002). Depremin ilköğretim öğrencilerinin güdülerini ve başarı-başarısızlık yüklemelerini etkileme düzeyi. Yüksek Lisansı Tezi, Sakarya Üniversitesi, Sosyal Bilimler Enstitüsü, Sakarya.

Shaw, R., Kobayashi, K.S.H., \& Kobayashi, M. (2004). Linking experience, education, perception and earthquake preparedness. Disaster Prevention and Management: An International Journal. 13(1), 39-49.

Sözen, E. (2019). The earthquake awareness levels of undergraduate students. Journal of Pedagogical Research, 3(2), 87-101.

Şenaslan, E. (2010). Orta öğretim coğrafya dersinde deprem konusunda coğrafi düşünme becerilerinin ölçülmesi. Yüksek Lisansı Tezi, Gazi Üniversitesi, Eğitim Bilimleri Enstitüsü, Ankara.

Tekin, Ö. \& Dikmenli, Y. (2021). Sınıf öğretmeni adaylarının afet bilinci algısı ve deprem bilgi düzeylerinin incelenmesi. Ahi Evran Üniversitesi Sosyal Bilimler Enstitüsü Dergisi, 7(1), 258-271.

Turoğlu, H. (2006). Orta öğretim coğrafya müfredatında yapılandırmacı öğrenme. Türk Coğrafya Dergisi, 115-130.

Yiğit, E., Boz, G., Gökçe, A. \& Özer, A. (2019). Tip ve mühendislik fakültesi öğrencilerinin afet konusundaki bilgi, tutum ve davranışları. 3. International 21. National Public Health Congress. Ekim 2019.

Yolcu, M. \& Bekler, T. (2020). Deprem kültürü ve farkındalık çalışmaları: şili ve elazı̆̆ depremlerinin karşılaştırılması. Lapseki Meslek Yüksekokulu Uygulamalı Araştırmalar Dergisi, 1(2), 71-82. 
Benzer, S. \& Arpalık, A. 5 (2), 2021, 107-119

Yükseler, M. (2019). Çanakkale Onsekiz Mart Üniversitesi Să̆llk Yüksekokulu 1. sinıf ögrencilerinin deprem bilinci bilgi düzeyleri. Yüksek Lisansı Tezi, Çanakkale Onsekiz Mart Üniversitesi, Eğitim Bilimleri Enstitüsü, Çanakkale. 